\title{
The optimization of UAV routing problem with a genetic algorithm to observe the damages of possible Istanbul earthquake
}

\section{Olası İstanbul depreminin hasarlarının gözlenmesi için İHA rotalama probleminin bir genetik algoritma ile eniyilenmesi}

\author{
Muhammed HALAT ${ }^{1}$ iD , Ömer ÖZKAN 2* iD \\ 1,2Industrial Engineering Department, Turkish Air Force Academy, National Defense University, Istanbul, Turkey. \\ muhammed.halat.1730@gmail.com, o.ozkan@hho.edu.tr
}

\begin{abstract}
In this study, the problem is to find a route for a UAV that takes off from Istanbul to observe the damages that may occur after the possible Istanbul earthquake within the first 24 hours. In the problem, 230 candidate grid points that UAV can visit on Istanbul are determined and the weight values combining the risk values based on earthquake degree zones and the population densities of the grid points are calculated for each candidate point. It is aimed to find a route for the $U A V$ to maximize the total weights of the visited grid points under the UAV range constraint. The described problem is adapted to the Orienteering Problem in the literature. Since the Orienteering Problem is an NP-hard problem, a problem-specific genetic algorithm and a simulated annealing algorithm are developed to solve the problem. The parameters of the algorithms are tuned by experiments. 15 different scenarios including the daily number of visits (of taken images) and the airports that the UAV takes and lands off after the earthquake are created and tried to be solved exactly via ILOG and approximately via developed metaheuristics. While the optimal solutions are found for 2 of 15 scenarios via ILOG, the designed genetic algorithm has better solutions and can solve the problem within acceptable CPU times for the rest of the scenarios.
\end{abstract}

Keywords: UAV routing, Vehicle routing, Genetic algorithm, Orienteering problem, Istanbul earthquake, Disaster management.

\section{Introduction}

Istanbul connects two continents (Europe and Asia) and it is the largest city in Europe with over 15 million population. The Bosphorus is the name of the strait between the two continents and it unites the Black Sea and the Marmara Sea. As a result of this geological location, Istanbul has experienced major earthquakes throughout its history, because the North Anatolian Fault passes under the Marmara Sea. The researches point in 2002 that in the following 30 years a major earthquake under the Marmara Sea is expected with a $65 \%$ probability. There are approximately 800000 buildings in Istanbul and it is estimated that the expected earthquake will cause to demolish 35000-40000 buildings. The loss of life will range from 30000 to 40000 . 70000 buildings will be heavily and 200000 will be moderately damaged. After the earthquake, 430000 to 600000 families will need shelters to live in. Just the damages of buildings will cost $\$ 11$ billion. The damages in roads, bridges and other transportation systems, electricity, water, and gas

\section{$\ddot{0} \mathrm{z}$}

Bu çalıșmada, olası İstanbul depremi sonrası olușabilecek hasarları havadan gözlemlemek için ilk 24 saat içerisinde İstanbul'dan kaldırılan bir IHA'nın hangi rotada uçması gerektiği problemi ele alınmıştır. Problemde, İstanbul üzerinde IHA'nın ziyaret edebileceği 230 aday grid nokta belirlenmiş ve her aday nokta için noktanın deprem riski ağırlığı ile nüfus yoğunluğunu birleștiren ağırlık değerleri belirlenmiștir. Problemde en fazla sayıda aday noktanın ağırlığını toplayacak șekilde iHA'nın menzil kısıtı altında rotalanması amaçlanmıștır. Tanımlanan bu problem, literatürdeki Oryantring problemine uyarlanmıștır. Oryantring problemi NP-zor bir problem olduğundan dolayl, problemin çözümü için probleme özgü bir genetik algoritma ve bir tavlama benzetimi algoritması geliştirilmistir. Algoritmaların parametreleri deneyler ile ayarlanmıștır. Gerçek hayata uygun olarak deprem sonrası IHA'nın kalktığı havalimanı ile günlük ziyaret (veya görüntü sayısı) durumlarını kapsayan 15 farklı senaryo olușturulmus ve senaryolar ILOG ile kesin ve gelistirilen metasezgisel algoritmalar ile yaklassk olarak çözülmeye çalışılmıştır. 15 senaryonun 2'sinde optimal çözüm bulunmus olup diğer senaryolar için genetik algoritma daha iyi sonuçlar elde etmiş ve kabul edilebilir CPU süreleri içinde problemi çözebilmiștir

Anahtar kelimeler: İHA rotalama, Araç rotalama, Genetik algoritma, Oryantring problemi, İstanbul depremi, Afet yönetimi. distribution systems, communication systems, etc. will also cause to create higher risks [1],[2].

These results can be reduced by effective and efficient pre- and post-disaster management. Therefore this paper focuses on observing the damages of the possible Istanbul earthquake via an Unmanned Aerial Vehicle (UAV). UAV technology is growing rapidly and it is becoming cheaper to use the UAVs in all types of military and civilian missions. The UAV types are categorized as micro, light, medium, heavy and super-heavy weighted with fixed, single rotary or multi rotary wings. They also may have long ( $\geq 400 \mathrm{~km}$.), medium $(400-100 \mathrm{~km}$.) or short $(\leq 100 \mathrm{~km}$.) flight ranges [3]. There are plenty of recent researches in the literature about the usage of UAVs for disaster management [4]-[8]. Most of the researchers focus on the conceptual usage of UAV, the image or video processing of a part of the land and there are also real implementations for small-sized areas with generally micro or light-weighted short-ranged UAVs for preand post-earthquake occasions.

${ }^{*}$ Corresponding author/Yazıșılan Yazar 
The main contribution of this paper is to solve a possible postdisaster case by using a long-range UAV for a quite big disaster area (i.e. Istanbul is $5461 \mathrm{~km}^{2}$ ). The possible post-earthquake damages in Istanbul can be detected via routing that type of UAV. As the second contribution of this study to the literature that the UAV Routing Problem (UAVRP) is formulated based on the Orienteering Problem (OP) and a literature review of OP is prepared. The problem is tried to solved exactly. As the last utility, a problem-specific Genetic Algorithm (GA) and Simulated Annealing (SA) algorithm are developed to solve the problem and real data for Istanbul is generated and used.

The study is organized as follows: Section 2 gives the relevant literature about the OP and UAV routing. The problem definition and the mathematical model of the problem are described in Section 3. Section 4 covers the proposed SA and GA, and section 5 presents the case study of the possible Istanbul earthquake. Finally, section 6 concludes the paper.

\section{Literature review}

Travelling Salesman Problem (TSP), Vehicle Routing Problem (VRP) and OP are well known and studied transportation based problems and UAVRP is an extension of these optimization problems for flying vehicles. There is a considerable amount of literature about TSP, VRP, UAVRP, OP and their variants [9]-[14]. This paper focuses on the OP because the defined problem in this paper is an implementation of OP. Therefore, a detailed literature review for $\mathrm{OP}$ and its variants are presented in Table 1.

OP is defined by Golden et. al. [16] and it has NP-hard complexity [16]. Thence as seen from Table 1, there are exact, heuristic, metaheuristic, approximation algorithms to solve the $\mathrm{OP}$ and its variants. The review papers about OP can be found in [27],[50].

Table 1. A literature review for the OP.

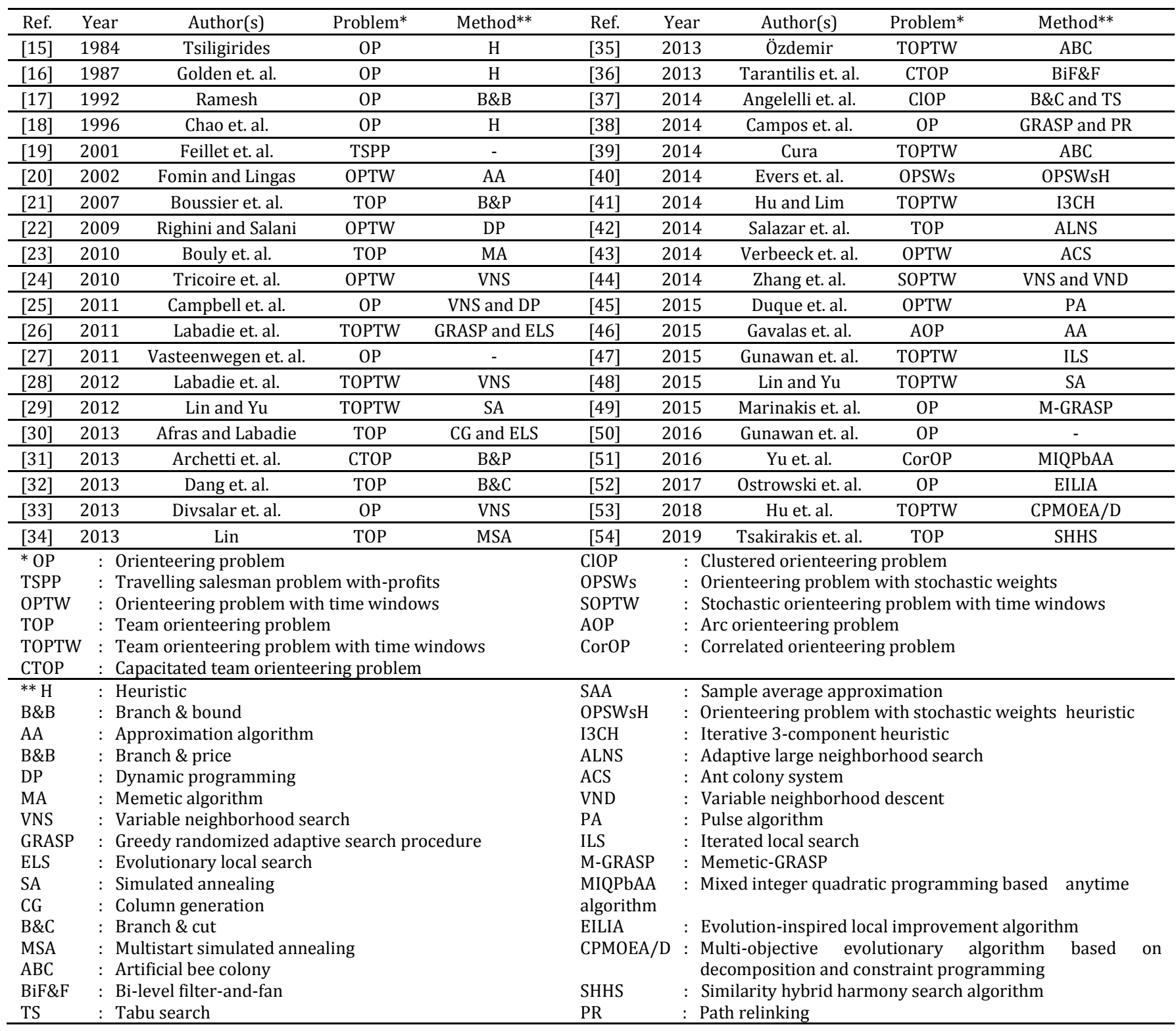


In TSP, the salesman starts with a node, visits all other nodes (i.e. customers) just one time and turns back to the starting node. In VRP, the vehicle does not have to turn back to the starting node or visit all other nodes. On the other hand different then TSP and VRP in OP, there are scores (i.e. weights) for all nodes separately and the traveler (i.e. runner or UAV for the solved problem in this paper) tries to collect maximum total score by visiting some of the nodes under a time constraint. The runner may or may not have to return to the starting node. In this paper, we also preferred to solve the OP exactly by using an Integer Programming (IP) model and approximately by using two metaheuristics for a real case study.

\section{Problem definition}

The OP can be defined as a graph $G=(N, E)$ with a set of nodes $(N)$ and a set of edges $(E)$. Each node $i$ has a score (i.e. weight) $S_{i}$. The $t_{i j}$ is the euclidean distance between nodes $i$ and $j$. The $T_{\text {max }}$ is the range limit to finish the tour and it is not necessary to visit all nodes. The goal of the $\mathrm{OP}$ is to find a route that maximizes the total collected score from the one time visited nodes. The starting and ending node may or may not be the same (in this paper, the UAV turns back to the departure base).

The OP can be formulated as an IP model and it is presented below [27]. The following decision variables $X_{i j}$ are used to represent the visited nodes, that $X_{i j}=1$ if a node is visited, otherwise $X_{i j}=0$. In the model, $u_{i}$ and $u_{j}$ are the positions of node $i$ and $j$ in the path that is used to prevent the sub-tours.

$$
\text { Max. } \sum_{i=2}^{N-1} \sum_{j=2}^{N} S_{i} X_{i j}
$$

s.t.

$$
\begin{gathered}
\sum_{j=2}^{N} X_{1 j}=\sum_{i=1}^{N-1} X_{i N}=1 \\
\sum_{i=1}^{N-1} X_{i k}=\sum_{j=2}^{N} X_{k j} \leq 1 ; \forall k=2, \ldots, N-1 \\
\sum_{i=1}^{N-1} \sum_{j=2}^{N} t_{i j} X_{i j} \leq T_{\max } \\
2 \leq u_{i} \leq N ; \forall i=2, \ldots, N \\
u_{i}-u_{j}+1 \leq(N-1)\left(1-X_{i j}\right) ; \forall i, j=2, \ldots, N \\
X_{i j} \in\{0,1\} ; \forall i, j=1, \ldots, N
\end{gathered}
$$

The objective function (1) maximizes the total collected score. Constraint (2) ensure that the route starts in node 1 and ends in node $N$ (1st and $N$ th nodes are the same nodes i.e. the base for this study). Constraint (3) guarantee the connectivity of the route and guarantee that every node is visited at most once. Constraint (4) ensures a limited UAV flight range. Constraints (5) and (6) are essential to prevent sub-tours.

\section{The methodology}

In this work, two metaheuristics (GA and SA) are developed to solve the problem. Their operators and parameters are described in the following subtitles.

\subsection{The genetic algorithm}

GA is a metaheuristic inspired by natural evolution [55]. The GA starts with multiple initial solutions (individuals) and this initial population evolves to better populations by the implementation of crossover, mutation, and selection (parental and environmental) operators. Better individuals create better children and in the end, the fittest solution can be reached. In this paper, since the OP is NP-hard [16], a problem-specific GA and SA are designed to solve the OP based UAVRP. GA is chosen because it is the most preferred and well-studied metaheuristic to solve the optimization problems in the literature. The pseudo-code of the proposed GA is presented in Figure 1.

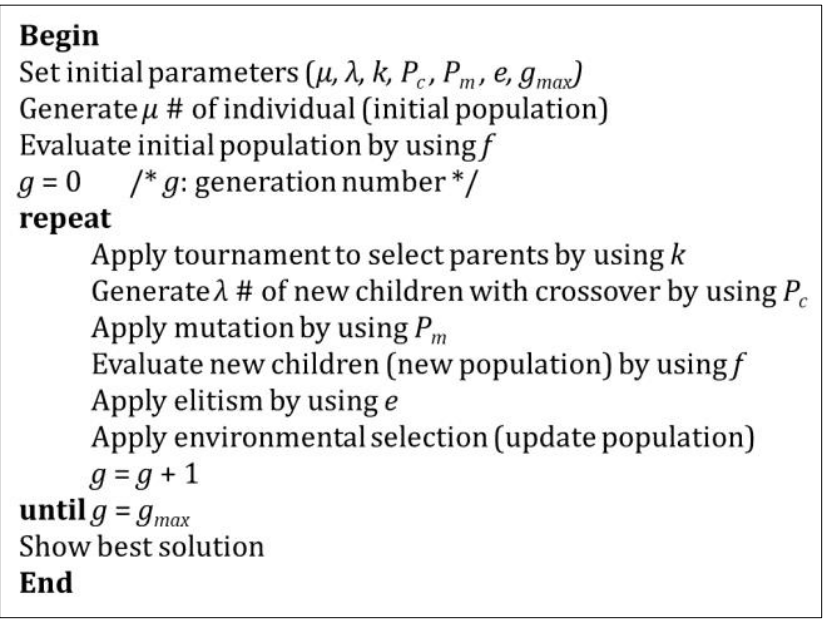

Figure 1. Pseudo-code of the proposed GA.

The following subtitles cover the basic operators and functions of the proposed GA based on Figure 1. The initial parameters presented in Figure 1 are also described in the following subtitles and they are tuned before implementing the case study.

\subsubsection{Representation}

The proposed GA uses a permutation-based representation. The representation has 2D permutation arrays and a sample is described in Figure 2.

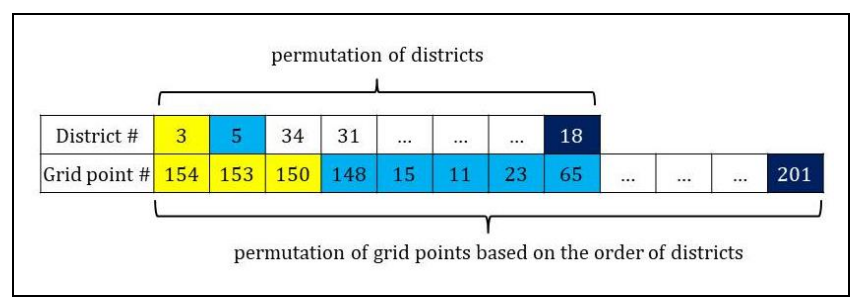

Figure 2. The 2D array permutation representation sample.

The first array is the permutation of districts and the second array is the permutation of candidate grid points that the UAV visits. The second row is related to the first row and the order of the second row is convenient to the first one. For instance in Figure 2, the first element of the first row is district 3 . In the second row, the first 3 candidate grid points are the points in district 3 (i.e. 154, 153, and 150 respectively). The second element of the first row is district 5 and the interval between the 4 th and the 9 th elements of the second row are the points that are located in district 5. The following cells in Figure 2 are obeying the same rule. As seen from Figure 2, since the number 
of the districts is less than the number of the candidate grid points, the length of the first row is shorter than the second row.

This representation is chosen because the OP based UAVRP is about finding a proper path for a UAV. Therefore, this representation helps not only see the order of the candidate grid points but also finds an efficient order of the districts to be visited. The following operators are using both rows to diversify the candidate solutions.

\subsubsection{Fitness function}

The fitness function $(f)$ of the proposed GA is a normalized function of the original objective function (Eq.1) and it is presented in Equation (8).

$$
\text { Max. } \sum_{i=2}^{N-1} \sum_{j=2}^{N} S_{i} X_{i j} / \sum_{i=2}^{N-1} S_{i} ; i, j=1, \ldots, N
$$

In Equation (8), the denominator is the total score of all candidate grid points. The obtained value of the Equation (8) ranges between " 0 " and " 1 ", therefore the calculated value provides a better approach to understand the total collected score by the visited candidate grid points via a UAV in a distance range constraint. When calculating an $f$ of a candidate solution, the distances between the visited grid points without considering the neighborhood of the districts are summed until reaching the range limit according to the order of the grid points. If the range of the UAV is reached before the end of the second row, it is accepted that the UAV is only visited some of the grid points in the order. If the entire candidate grid points are visited for a candidate solution, then the $f$ of the individual becomes "1", otherwise it is $<1$. The proposed GA does not produce any infeasible solution, but the length of the second row in the representation also does not change according to the individuals.

\subsubsection{Initial population}

The initial population of the proposed GA has $\mu$ number of solutions (i.e. $\mu=$ population size) and this parameter is tuned before case study. The initial individuals are created with a simple heuristic. Instead of using random solutions, it is preferred to use a heuristic, because it is important to create a balance between the diversification and intensification property of a GA. The random solutions help to diversify, but they generally have worse $f$ value. The proposed heuristic uses neighborhood properties of the districts to also increase the intensification. The heuristic starts with selecting a random neighbor district of the base station (i.e. an airport). Then, the heuristic randomly selects a neighbor district of the previously selected district. The process continues until selecting all districts. If all of the neighbors of a selected district are already in the solution, the heuristic selects a random district and the procedure continues. After finding a proper permutation for the districts, the heuristic finds an order for the candidate grid points of the districts convenient to the permutation of the districts. The candidate grid points of a district in the order are sorted randomly as the second row. The heuristic helps to find good initial solutions and prevents the UAV to fly inefficiently between distant grid points.

\subsubsection{Parental selection and crossover}

After generating the initial population, the proposed GA determines the parents by using tournament selection. In tournament selection, the $k$ numbers of randomly selected individuals encounter in a tournament and the best $f$ valued winner individual becomes a parent. Then by using crossover probability $\left(P_{c}\right)$, the order 1 crossover is implemented which is convenient to the permutation-based representations. A sample for the order 1 crossover is presented in Figure 3.

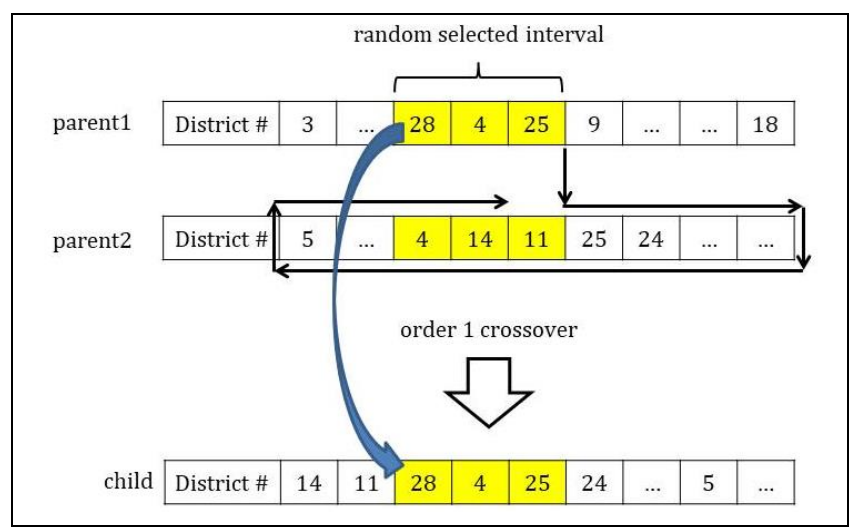

Figure 3. The order 1 crossover sample.

As seen in Figure 3, the order 1 crossover transfers a randomly selected interval (i.e. 28, 4 and 25) of the parent 1 with in the same position to the child. Then, it continues with the parent 2 from the following cell and copies the unvisited districts to the child until reaching to the end of the solution. When reaches the end, it turns back to the initial cells of the parent 2 and continues to transfer the unvisited districts to the child till the end. The order 1 crossover prevents to create an inconvenient child for the permutation representation. Finally, the candidate grid points of the parents are transferred to the child from the original parent that the gene (i.e. districts) is copied. And, the order of the second row is convenient with the first row (i.e. the order of the districts) in the produced child. The order 1 crossover does not change the internal order of candidate grid points in districts.

\subsubsection{Mutation}

The order 1 crossover generally tries to find the best route for the districts. However, the order of the candidate grid points is also important to reach better solutions. Therefore, two different mutations are used by the proposed GA to help to find better routes. The first mutation is district swap mutation and a sample for the mutation operator is covered in Figure 4.

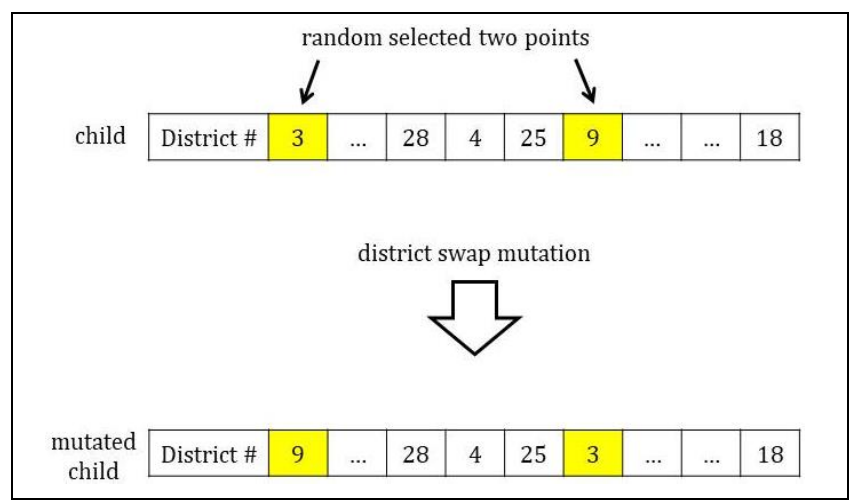

Figure 4. The district swap mutation sample.

The district swap mutation simply swaps the orders of the two random selected districts of a selected solution (i.e. 3 and 9 in Figure 4). The candidate grid points of the selected districts are also changing their orders according to the new arrangement. 
The second mutation is candidate grid point scramble mutation and a sample for the created problem-specific mutation operator is covered in Figure 5.

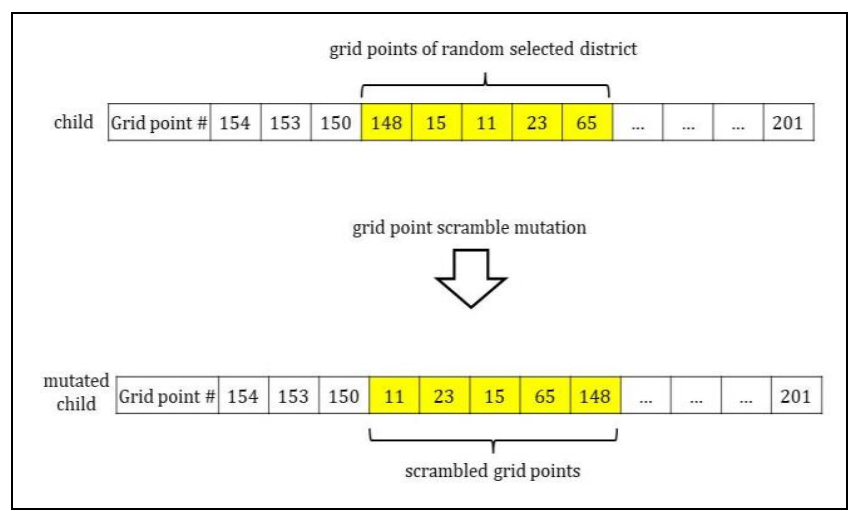

Figure 5. The grid point scramble mutation sample.

The grid point scramble mutation tries to find better sub-routes for the internal order of the districts. As seen in Figure 5, five grid points of a randomly selected district are scrambled randomly to find a new solution. The mutation probability $\left(P_{m}\right)$ is used to select the children to be mutated and it is tuned before case study. The designed mutation operators are trying to make small changes in the order of the selected individuals to increase the intensification property of the proposed GA.

\subsubsection{Environmental selection, elitism and stopping criteria}

The proposed GA produces $\lambda=\mu-e * \mu$ number of new children in every generation where $0<e<1$. In the environmental selection, the $e * \mu$ number of elitist (i.e. the best) solutions of the previous generation join the $\lambda$ number of new solutions to generate the next generation. Therefore, $\mu$ stays constant during generations. The proposed GA stops when it reaches to $g_{\max }$ number of generations. The $e$ and $g_{\max }$ parameters are also tuned before the case study.

\subsection{The simulated annealing}

The SA is a single solution based metaheuristic that can escape from local extremums by using a temperature parameter and a cooling schedule for this parameter [56]. The pseudo-code of the generated SA for the problem is illustrated in Figure 6.

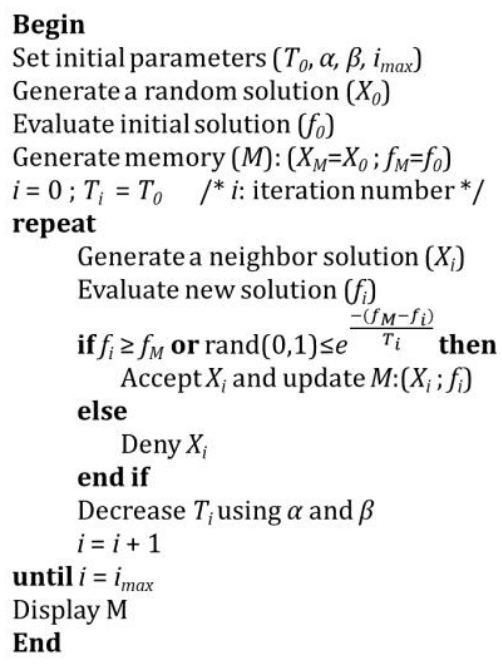

Figure 6. Pseudo-code of the SA.
The second row of the representation in the GA (i.e. grid points) is used as the representation of the solutions in the SA. The fitness value calculation of the GA is the same for the SA. The initial temperature $\left(T_{0}\right)$ of SA is calculated by a Markov chainbased algorithm proposed by [56]. In the algorithm, the $T_{0}$ is set at a temporary large number for the Markov chain at the start and after a full Markov chain is accomplished, $T_{0}$ is calculated by using the following Equation (9).

$$
\gamma=\frac{m_{1}+m_{2} x e^{\frac{-\Delta f}{T_{0}}}}{m_{1}+m_{2}}
$$

In Equation (9), $m_{1}$ covers the number of moves that have resulted in an increased $f$ value, $m_{2}$ represents the moves when the $f$ value decreased relative to the previous step, and $\Delta f$ represents the average $f$ increase after $m_{2}$ moves. The acceptance ratio $(\gamma)$ of the worse results is set to $95 \%$ at the start, it is decreased subsequently. The determined maximum iteration number $\left(i_{\max }\right)$ is divided into $\beta$ parts equally and at the end of each division, the temperature is decreased to $T_{i+1}=$ $\alpha * T_{i}(i=0,1,2, \ldots)$ beginning with $T_{0}$. The $\alpha, \beta$, and $i_{\max }$ parameters are tuned before the case study.

\section{The case study: The Istanbul earthquake}

Istanbul is selected as the case study for the OP based UAVRP implementation to the post-earthquake situations. Because it is the most crowded city in Europe and the coming earthquake near Istanbul is inevitable. The degree of earthquake zones in Istanbul is presented in Figure 7.

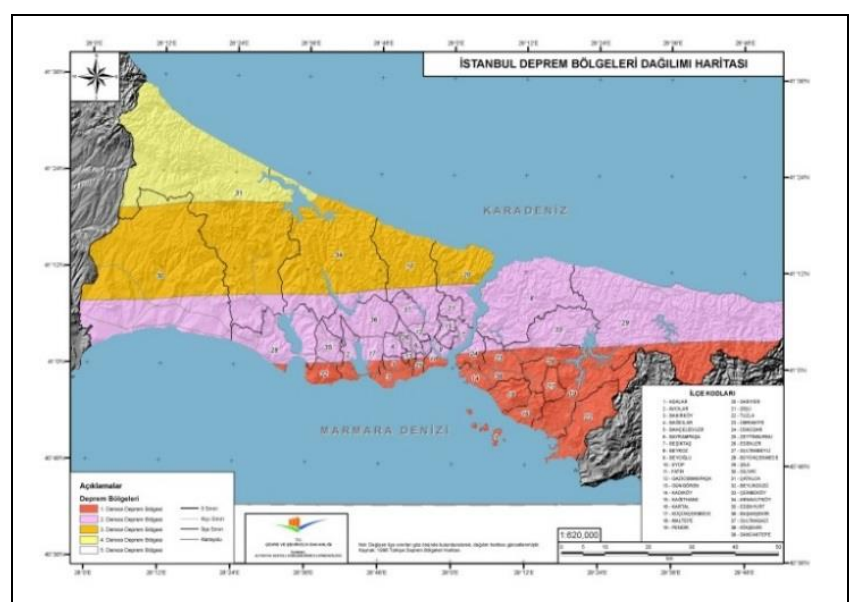

Figure 7. The degree of earthquake zones in Istanbul [57],[58].

As seen from Figure 7, four different zones have different earthquake degrees in Istanbul (from 1st to 4 th degree and illustrated as red, purple, orange and yellow-colored, respectively). The risk of the zones decreases when the zone becomes away from the Marmara Sea.

The map in Figure 7 is placed on Google Earth software and the map is overlapped with the exact Istanbul map on Google Earth. The overlapped maps are presented in Figure 8.

By using the map in Figure 8, the exact locations of the earthquake zones are determined. Then, the Istanbul map is divided into grid zones which have $10 \mathrm{~km}$. to $10 \mathrm{~km}$. edge lengths (i.e. the grid zones are covering $100 \mathrm{~km}^{2}$ ) and the GPS coordinates of the 230 number of candidate grid points in Istanbul are determined as presented in Figure 9. The airports (i.e. the base stations) in Istanbul are also marked as stars in 
Figure 9 and their GPS coordinates are also determined via Google Earth. The GPS coordinates of the candidate grid points and the airports are used to calculate Euclidean distances between them.

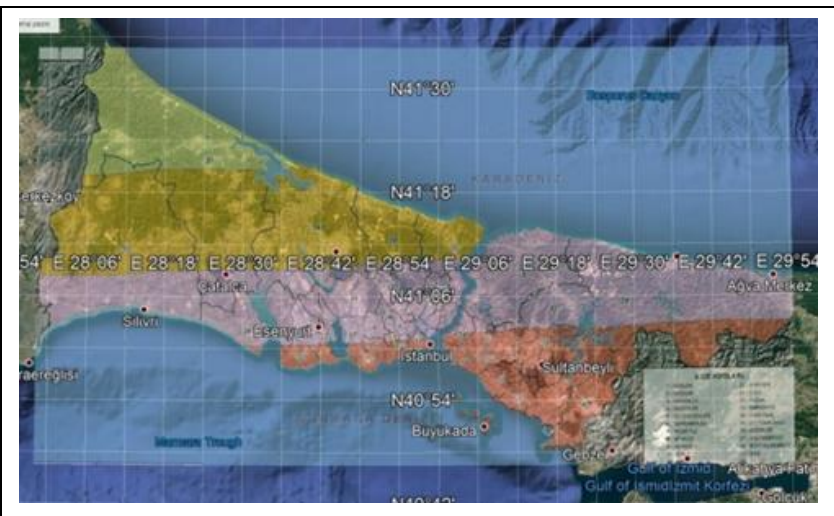

Figure 8. The overlapped Istanbul earthquake map on Google Earth.

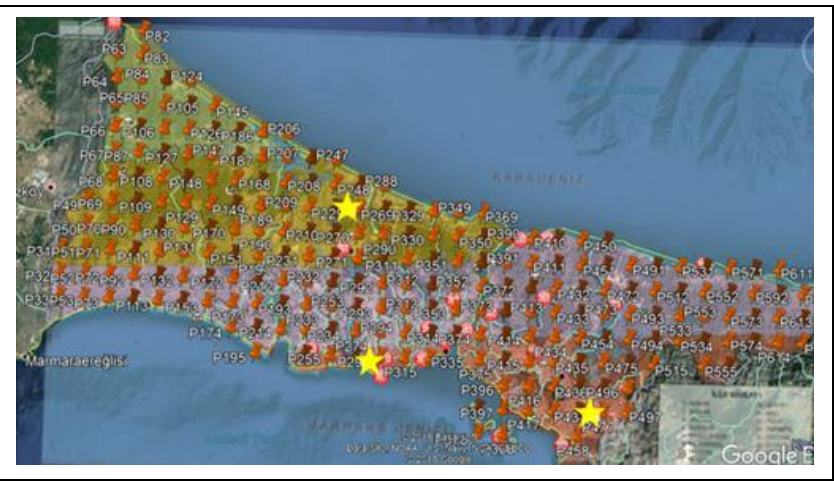

Figure 9. 230 candidate grid points (pins) and 3 base stations (stars, i.e. the airports in Istanbul).

The length of the edges of the grid zones is determined conveniently to the selected UAV which is named Bayraktar. The Bayraktar UAV is a long-ranged (3000 km.) Turkish made $\mathrm{UAV}$ and it is an appropriate UAV for that kind of mission. The Bayraktar can get the desired images and videos from that sized zones by flying in a proper altitude. A sample figure for the coverage of the grid zones by visiting the grid points in the center of the grid zones via a Bayraktar UAV is illustrated in Figure 10.

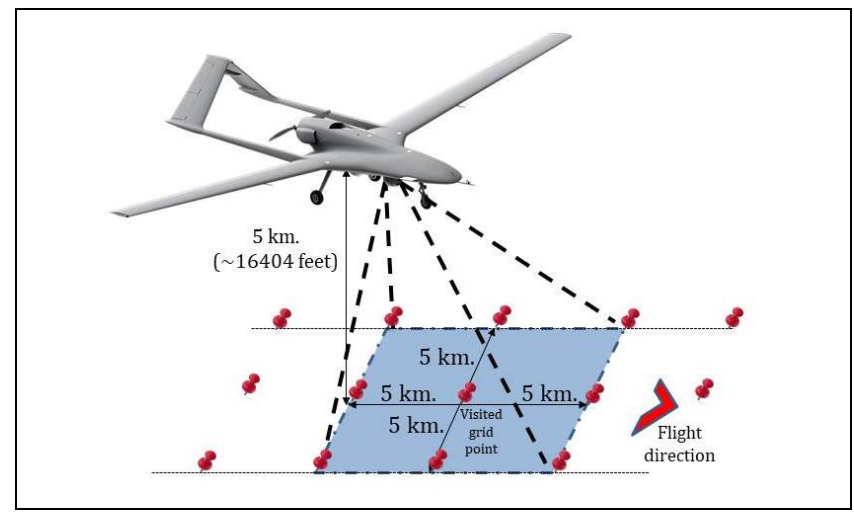

Figure 10 . The coverage of a grid zone by visiting the grid point in the center (i.e. pin in the center of the covered area) via a Bayraktar UAV.
After determining the candidate grid points and their locations, the population and the earthquake risk values for each grid point are calculated. Istanbul has more than 15 million population and has 39 districts. Most of the population is close to the Marmara and that can increase the losses for a possible earthquake. The density of the population in districts is illustrated in Figure 11.

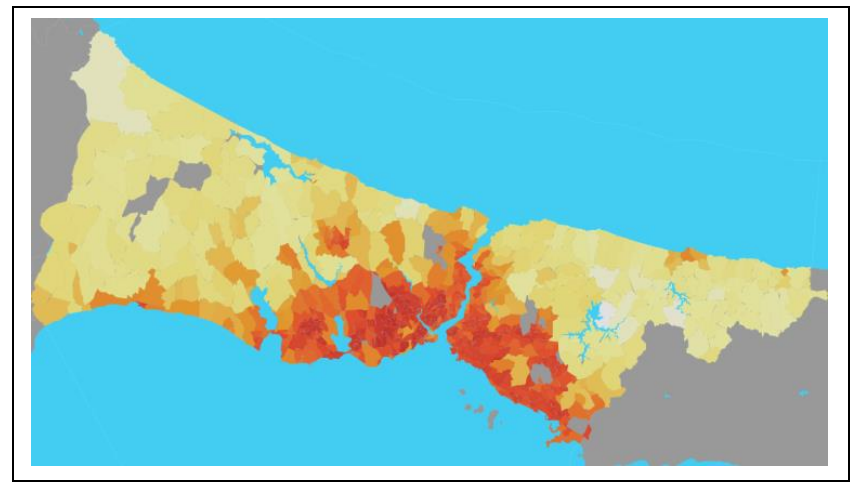

Figure 11. The population density in districts of Istanbul [60].

The exact population of districts, their neighbor district(s) and the total number of grid points located in the districts are presented in Table 2. As figured out from the table, there are 34 rows, because 5 of 39 districts are added to the nearest neighbor districts since they do not have any grid points on them. While calculating the population of a grid point, the population of the district that the grid is located is divided into the total number of grid points in that district.

After the calculation of the population of the grid points, the risk values of the grid points are determined. The 4 different degrees of earthquake zones in Istanbul illustrated in Figure 7 are evaluated by the experts in Kandilli Observatory and Earthquake Research Institute, Boğaziçi University in Turkey. Their assessments are presented in Table 3.

Table 3 also provides information about the number of grid points in the 4 different degrees of earthquake zones. More than half of the grid points are placed in the first 2 degrees of earthquake zones which can cause to increase the possible losses after a possible earthquake.

The overall weights (scores) of the grid points are calculated by multiplying their population and the risk values. Consequently, 15 different scenarios are created to solve the problem within different cases and parameters. The scenarios are summarized in Table 4.

According to the scenarios, the airports in Istanbul are selected as the origin nodes that the Bayraktar UAV takes and lands off. Since the Bayraktar has $3000 \mathrm{~km}$. range, the range is divided into 5 different numbers to represent the number of daily visits to the selected grid points in candidate solutions. The number of daily visits is ranged from 1 to 5 and therefore the range of Bayraktar is limited with 3000 to $600 \mathrm{~km}$., respectively. Visiting the grid points more than one time is considered to monitor the effects of possible aftershock earthquakes and the new good and bad incidents. After such an earthquake, new collapses, fires or explosions may happen or aftershock earthquakes can trigger more devastating events. In a good manner, some roads can be cleared or some fires may be put out. Therefore, it seems reasonable to observe the grid points for more than one time in the first 24 hours of the possible earthquake. 
Table 2. The districts of Istanbul and their specifications [59].

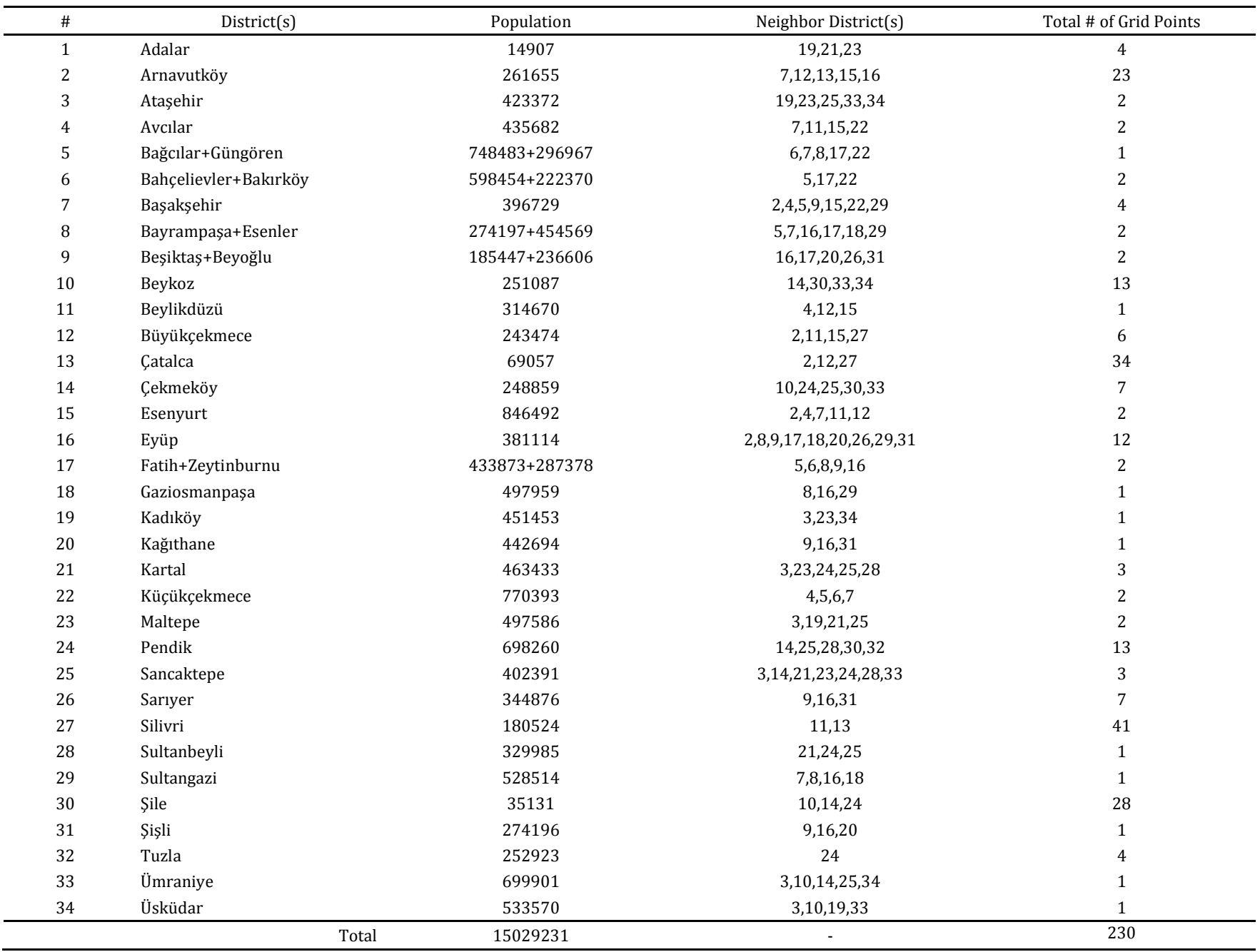

Table 3. Earthquake zones in Istanbul and their risk values.

\begin{tabular}{ccc}
\hline Degree of the Earthquake Zone & Risk Value & Total \# of Grid Points \\
\hline $1^{\text {st }}$ & 0.4 \\
$2^{\text {nd }}$ & 0.3 & 42 \\
$3^{\text {rd }}$ & 0.2 & 63 \\
$4^{\text {th }}$ & 0.1 & 29 \\
\hline Total & 1 & 230 \\
\hline
\end{tabular}

Table 4. Scenarios.

\begin{tabular}{|c|c|c|c|}
\hline$\#$ & Base Station & Number of daily visits & Range of UAV (km.) \\
\hline 1 & & 1 & 3000 \\
\hline 2 & & 2 & 1500 \\
\hline 3 & Atatürk Airport & 3 & 1000 \\
\hline 4 & & 4 & 750 \\
\hline 5 & & 5 & 600 \\
\hline 6 & & 1 & 3000 \\
\hline 7 & & 2 & 1500 \\
\hline 8 & Sabiha Gökçen Airport & 3 & 1000 \\
\hline 9 & & 4 & 750 \\
\hline 10 & & 5 & 600 \\
\hline 11 & & 1 & 3000 \\
\hline 12 & & 2 & 1500 \\
\hline 13 & Istanbul Airport & 3 & 1000 \\
\hline 14 & & 4 & 750 \\
\hline 15 & & 5 & 600 \\
\hline
\end{tabular}


The parameters of the proposed GA and SA are tuned by using the first scenario. 30 runs are made for each combination of the parameters by running with the candidate values. The bestresulted values for the parameters are selected according to 2430 runs for GA and 270 runs for the SA. The assigned values are presented in Table 5 . The $\mu$ and $g_{\max }$ parameters are considered as pairs. Since the GA is using $\mu * g_{\max }=10000$ number of solutions to reach better solutions in all generations, the $i_{\max }$ parameter of the SA is also set to 10000 to make a fair comparison.

Table 5. Tuned and assigned parameters.

\begin{tabular}{|c|c|c|c|}
\hline Algorithm & Parameter(s) & $\begin{array}{c}\text { Candidate } \\
\text { values }\end{array}$ & $\begin{array}{c}\text { Assigned } \\
\text { value(s) }\end{array}$ \\
\hline \multirow{13}{*}{ GA } & \multirow{3}{*}{$\mu, g_{\max }$} & 20,500 & \\
\hline & & 50,200 & 20,500 \\
\hline & & 100,100 & \\
\hline & \multirow{3}{*}{$e$} & 0.1 & \multirow{3}{*}{0.2} \\
\hline & & 0.2 & \\
\hline & & 0.3 & \\
\hline & $P_{c}$ & - & 1 \\
\hline & \multirow{3}{*}{$P_{m}$} & 0.1 & \multirow{3}{*}{0.3} \\
\hline & & 0.2 & \\
\hline & & 0.3 & \\
\hline & \multirow{3}{*}{$k$} & 3 & \multirow{3}{*}{7} \\
\hline & & 5 & \\
\hline & & 7 & \\
\hline \multirow{8}{*}{ SA } & $T_{0}$ & - & $0.1035^{\circ}$ \\
\hline & & 0.9 & \multirow{3}{*}{0.99} \\
\hline & $\alpha$ & 0.95 & \\
\hline & & 0.99 & \\
\hline & \multirow{3}{*}{$\beta$} & 200 & \multirow{3}{*}{200} \\
\hline & & 500 & \\
\hline & & 1000 & \\
\hline & $i_{\max }$ & - & 10000 \\
\hline
\end{tabular}

The proposed GA and SA are coded in MATLAB, and the mathematical model is tried to be solved via ILOG CPLEX 12.6.1. The runs of metaheuristics and the mathematical model are made on the same computer that has Intel Core I5-7500U CPU, $3.40 \mathrm{GHz}$, and $8 \mathrm{~GB}$ RAM specifications. By using the tuned parameter values, the provided results by the proposed GA, SA and the model for each scenario are illustrated in Table 6 .

According to the results, the ILOG CPLEX found the optimal solutions just for the 2 of 15 scenarios. Both optimal solutions can cover 230 of 230 grid points on Istanbul (i.e. $f=1$ for the 6 th and the 11th scenarios) that means even by considering the weight values of the grid points the UAV can monitor the possible damages in overall the city in the first 24 hours after the possible earthquake within $3000 \mathrm{~km}$. flight range. Without considering the weights of the grid points the UAV can fly in a straighter route and can get more information. The best route of the UAV for scenario 11 found by ILOG CPLEX is drawn in Figure 12. As seen, the overall grid points in Istanbul are visited just one time.

For the rest of the scenarios except 6 and 11, the GA has the highest fitness values than the SA as seen in Figure 6. The GA has better solutions in almost all scenarios for the best, mean and worst columns. The GA has relatively high fitness values (i.e. $f>0.9$ ), therefore these are good results for the problem that the UAV is observing most of the highest scored (weighted) grid points (i.e. more risky and crowded regions). It can be interpreted that most of the effects of the possible earthquake in Istanbul can be monitored by a Bayraktar UAV in a day in all scenarios. The visited grid numbers can be increased by refueling the UAV at the airport after the first flight. In the other scenarios, visiting the same selected grid points 5 times in a day is decreasing the best $f$ values of GA to $0.880,0.881$ and 0.899 . And the visited grid points are ranging between 29 and 42 for the GA. In these scenarios, just some of the important grid points can be observed. All results are ranging between 189 and 29 grid points. The best route of the UAV for scenario 11 found by GA is illustrated in Figure 13.

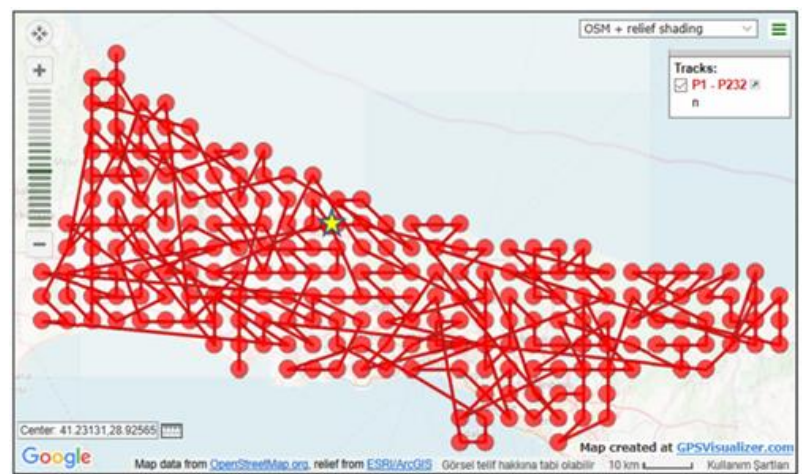

Figure 12. The best route result of ILOG CPLEX for scenario 11 with covering 230 of 230 grid points (i.e. $f=1$ ) starting from and ending at Istanbul Airport (i.e. star).

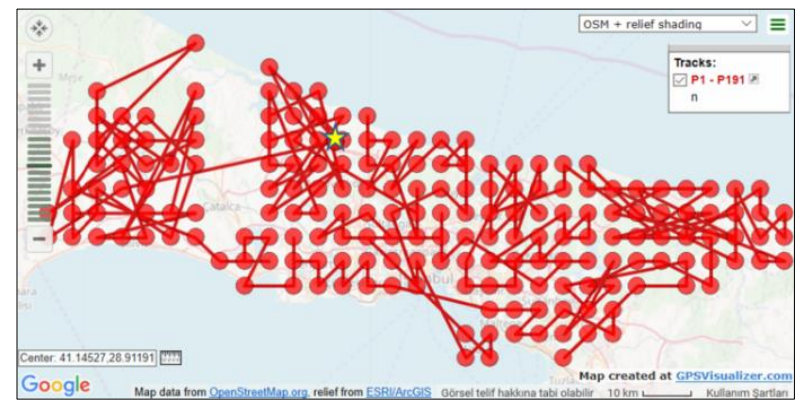

Figure 13. The best route result of GA for scenario 11 with covering 189 of 230 grid points (i.e. $f=0.999$ ) starting from and ending at Istanbul Airport (i.e. star).

The t-tests are conducted for each scenario and according to the test results GA has better results than SA in all scenarios ( $p$ values are ranging from 0.037889 to $2.82 \times 10^{-26}$ ). The boxplots of the results that illustrate the superiority of the proposed GA are also presented in Figure 14. The proposed GA can solve the scenarios between 4.51 to 10.97 seconds, and the SA is 0.81 to 3.58 seconds as seen in Table 7.

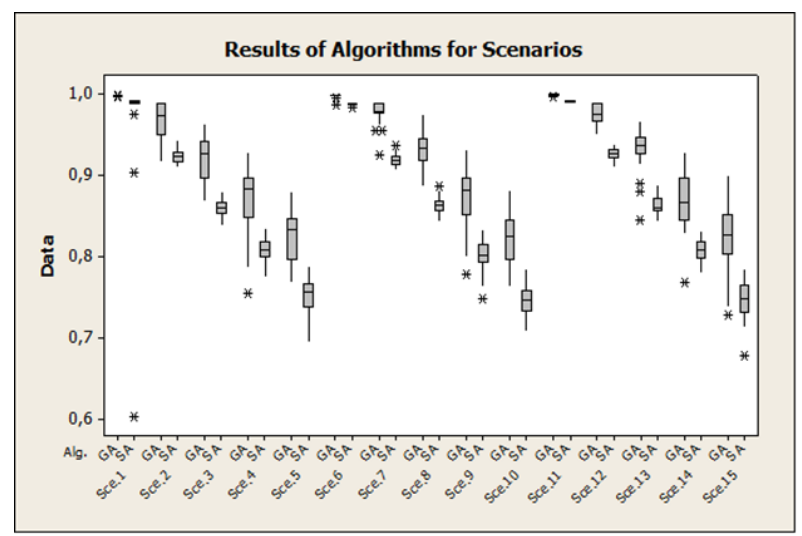

Figure 14. The boxplots of the results 
Table 6. The results for the scenarios.

\begin{tabular}{|c|c|c|c|c|c|c|c|c|c|c|}
\hline \multirow[b]{2}{*}{ \# } & \multirow[b]{2}{*}{$\begin{array}{c}\text { Exact } \\
\text { solution }\end{array}$} & \multirow{2}{*}{$\begin{array}{l}\text { Visited \# of } \\
\text { grid points } \\
\text { for the } \\
\text { exact } \\
\text { solution }\end{array}$} & \multicolumn{4}{|c|}{$\mathrm{GA}$} & \multicolumn{4}{|c|}{ SA } \\
\hline & & & $\begin{array}{c}\text { Best } \\
\text { fitness }\end{array}$ & $\begin{array}{c}\text { Mean } \\
\text { fitness }\end{array}$ & $\begin{array}{l}\text { Worst } \\
\text { fitness }\end{array}$ & $\begin{array}{l}\text { Visited \# of } \\
\text { grid points } \\
\text { for the best } \\
\text { fitness }\end{array}$ & $\begin{array}{c}\text { Best } \\
\text { fitness }\end{array}$ & $\begin{array}{c}\text { Mean } \\
\text { fitness }\end{array}$ & $\begin{array}{l}\text { Worst } \\
\text { fitness }\end{array}$ & $\begin{array}{l}\text { Visited \# of } \\
\text { grid points } \\
\text { for the best } \\
\text { fitness } \\
\end{array}$ \\
\hline 1 & $\mathrm{~N} / \mathrm{A}$ & $\mathrm{N} / \mathrm{A}$ & 0.999 & 0.998 & 0.997 & 170 & 0.993 & 0.974 & 0.603 & 154 \\
\hline 2 & $\mathrm{~N} / \mathrm{A}$ & $\mathrm{N} / \mathrm{A}$ & 0.989 & 0.968 & 0.917 & 106 & 0.943 & 0.923 & 0.909 & 85 \\
\hline 3 & $\mathrm{~N} / \mathrm{A}$ & $\mathrm{N} / \mathrm{A}$ & 0.964 & 0.922 & 0.868 & 66 & 0.880 & 0.860 & 0.838 & 62 \\
\hline 4 & $\mathrm{~N} / \mathrm{A}$ & $\mathrm{N} / \mathrm{A}$ & 0.929 & 0.870 & 0.754 & 60 & 0.835 & 0.807 & 0.774 & 47 \\
\hline 5 & $\mathrm{~N} / \mathrm{A}$ & $\mathrm{N} / \mathrm{A}$ & 0.880 & 0.823 & 0.768 & 41 & 0.788 & 0.751 & 0.695 & 38 \\
\hline 6 & 1 & 230 & 0.999 & 0.998 & 0.987 & 185 & 0.990 & 0.987 & 0.982 & 139 \\
\hline 7 & $\mathrm{~N} / \mathrm{A}$ & $\mathrm{N} / \mathrm{A}$ & 0.990 & 0.978 & 0.924 & 107 & 0.936 & 0.919 & 0.907 & 78 \\
\hline 8 & $\mathrm{~N} / \mathrm{A}$ & $\mathrm{N} / \mathrm{A}$ & 0.975 & 0.931 & 0.886 & 49 & 0.887 & 0.862 & 0.842 & 61 \\
\hline 9 & $\mathrm{~N} / \mathrm{A}$ & $\mathrm{N} / \mathrm{A}$ & 0.932 & 0.873 & 0.778 & 45 & 0.833 & 0.802 & 0.747 & 45 \\
\hline 10 & $\mathrm{~N} / \mathrm{A}$ & $\mathrm{N} / \mathrm{A}$ & 0.881 & 0.821 & 0.763 & 29 & 0.785 & 0.745 & 0.707 & 37 \\
\hline 11 & 1 & 230 & 0.999 & 0.999 & 0.997 & 189 & 0.993 & 0.991 & 0.989 & 156 \\
\hline 12 & $\mathrm{~N} / \mathrm{A}$ & $\mathrm{N} / \mathrm{A}$ & 0.990 & 0.974 & 0.949 & 97 & 0.938 & 0.926 & 0.910 & 81 \\
\hline 13 & $\mathrm{~N} / \mathrm{A}$ & $\mathrm{N} / \mathrm{A}$ & 0.966 & 0.932 & 0.844 & 47 & 0.889 & 0.863 & 0.843 & 63 \\
\hline 14 & $\mathrm{~N} / \mathrm{A}$ & $\mathrm{N} / \mathrm{A}$ & 0.928 & 0.867 & 0.767 & 41 & 0.831 & 0.807 & 0.780 & 47 \\
\hline 15 & $\mathrm{~N} / \mathrm{A}$ & $\mathrm{N} / \mathrm{A}$ & 0.899 & 0.822 & 0.727 & 42 & 0.784 & 0.748 & 0.677 & 40 \\
\hline & & \multicolumn{4}{|c|}{ GA } & & \multirow{2}{*}{\multicolumn{3}{|c|}{$\begin{array}{c}\text { SA } \\
\text { Mean }\end{array}$}} & \\
\hline \# & Exact & \multicolumn{3}{|r|}{ Mean } & \multicolumn{2}{|l|}{ Worst } & & & & Worst \\
\hline 1 & $\mathrm{~N} / \mathrm{A}$ & 9.62 & & 10.33 & 10.97 & & 1.70 & \multicolumn{2}{|c|}{3.20} & 3.58 \\
\hline 2 & $\mathrm{~N} / \mathrm{A}$ & 6.45 & & 7.13 & 7.61 & & 1.75 & \multicolumn{2}{|c|}{1.84} & 2.00 \\
\hline 3 & $\mathrm{~N} / \mathrm{A}$ & 5.55 & & 6.13 & 6.67 & & 1.24 & \multicolumn{2}{|c|}{1.32} & 1.47 \\
\hline 4 & $\mathrm{~N} / \mathrm{A}$ & 5.10 & & 5.48 & 5.10 & & 0.99 & \multicolumn{2}{|c|}{1.06} & 1.16 \\
\hline 5 & $\mathrm{~N} / \mathrm{A}$ & 4.71 & & 4.97 & 5.43 & & 0.83 & \multicolumn{2}{|c|}{0.90} & 0.98 \\
\hline 6 & 432 & 9.74 & & 10.26 & 10.77 & & 2.91 & \multicolumn{2}{|c|}{3.13} & 3.25 \\
\hline 7 & $\mathrm{~N} / \mathrm{A}$ & 6.80 & & 7.32 & 7.81 & & 1.69 & \multicolumn{2}{|c|}{1.81} & 1.98 \\
\hline 8 & $\mathrm{~N} / \mathrm{A}$ & 5.45 & & 5.90 & 6.31 & & 1.19 & \multicolumn{2}{|c|}{1.32} & 1.46 \\
\hline 9 & $\mathrm{~N} / \mathrm{A}$ & 4.72 & & 5.27 & 5.59 & & 0.97 & \multicolumn{2}{|c|}{1.05} & 1.18 \\
\hline 10 & $\mathrm{~N} / \mathrm{A}$ & 4.59 & & 4.81 & 5.06 & & 0.82 & \multicolumn{2}{|c|}{0.88} & 0.93 \\
\hline 11 & 817 & 9.89 & & 10.11 & 10.44 & & 3.18 & \multicolumn{2}{|c|}{3.37} & 3.52 \\
\hline 12 & $\mathrm{~N} / \mathrm{A}$ & 6.91 & & 7.28 & 7.67 & & 1.75 & \multicolumn{2}{|c|}{1.89} & 2.04 \\
\hline 13 & $\mathrm{~N} / \mathrm{A}$ & 5.60 & & 6.06 & 6.79 & & 1.24 & \multicolumn{2}{|c|}{1.38} & 1.53 \\
\hline 14 & $\mathrm{~N} / \mathrm{A}$ & 5.00 & & 5.30 & 5.74 & & 0.97 & \multicolumn{2}{|c|}{1.11} & 1.18 \\
\hline 15 & $\mathrm{~N} / \mathrm{A}$ & 4.51 & & 4.87 & 5.15 & & 0.81 & \multicolumn{2}{|c|}{0.91} & 1.03 \\
\hline
\end{tabular}

The convergence of the proposed GA from initial solutions to better individuals can be seen in Figure 15. In Figure 15, the best and the mean $f$ values of the generations are given for a sample run. The proposed GA is increasing the initial best $f$ value from 0.5457 to 0.9375 levels at the end of the run (i.e. in 500 generations). The mean $f$ values of the generations are also close to the best $f$ values of the generations that mean the individuals in the generations are becoming similar to each other as a clue for the convergence.

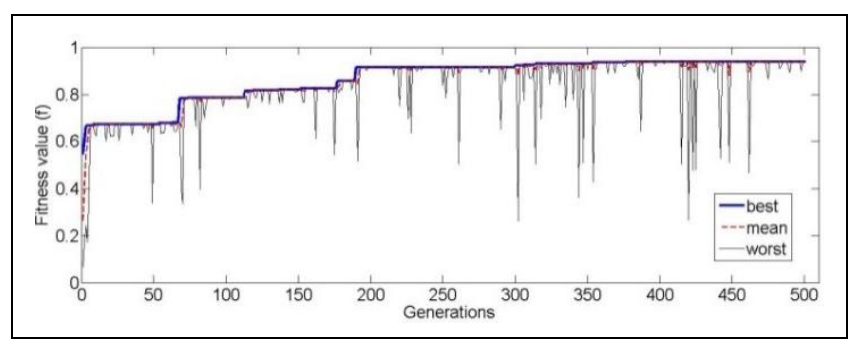

Figure 15. The convergence of GA for a sample run.

\section{Conclusion}

In this paper, the problem is to find a route for a UAV to observe the possible damages that can be occurred by an expected Istanbul earthquake. The UAV takes off from Istanbul within the first 24 hours. In the problem, 230 candidate grid points that can be visited by UAV at Istanbul are determined. The weight values (scores) for all candidate grid points are determined by combining the risk values based on earthquake degree zones and the population densities of the points. It is aimed to find a route for the UAV to maximize the total weights of the visited grid points under a range constraint. The described problem is adapted to the OP in the literature. Since the OP is an NP-hard problem, a problem-specific GA and SA are developed to solve the problem. The parameters of the GA and SA are tuned by experiments. 15 different scenarios including the daily number of visits and the airports that the UAV takes and lands off after the earthquake are created. The scenarios are solved with proposed GA, SA, and a mathematical model. The IP model found optimal solutions for 2 of 15 scenarios. The proposed GA has better solutions for the remaining scenarios, and it has 
reasonable CPU times (4.51 to $10.97 \mathrm{CPU}$ seconds). Bayraktar UAV can visit up to 230 of 230 grid points in a day after a possible earthquake depending on the scenario. The solutions seem acceptable for such a disaster case. It is believed that the defined problem is very vital and there should be more studies about the post-earthquake scenarios for the inevitable Istanbul earthquake. For future research, another metaheuristic, matheuristic, hyperheuristic, or simheuristic methods and their hybrid versions can be tried for the defined problem. The results can be compared with the proposed GA results. Besides, the problem can be turned into a dynamic problem or there can be used more than one UAV. Some of the UAVs can keep going to monitor when they capture a happening incident (a fire for instance) by flying over the incident continuously. Other UAVs can continue to cover the remaining grid points dynamically. Small types of UAVs (i.e. short ranged drones) can also be tried for each district separately, and the total costs can be compared with the proposed GA solution. Other constraints can be added or multi-objective models are also can be created.

\section{Acknowledgment}

We would like to thank Kandilli Observatory and Earthquake Research Institute staff for their valuable support in the process of determining risk values of the earthquake zones. We are grateful to the anonymous reviewers and the editorial board for their helpful and constructive advices.

\section{Author contribution statements}

In the scope of this study, Muhammed Halat contributed to the formation of the idea, literature review, algorithm design, obtaining the results. Ömer Özkan contributed to the formation of the idea, literature review, algorithm design, obtaining and evaluating the results and writing and reviewing the manuscript.

\section{Ethics committee approval and conflict of interest statement}

There is no need to obtain permission from the ethics committee for the article prepared.

There is no conflict of interest with any person / institution in the article prepared.

\section{References}

[1] Boğaziçi Üniversitesi, Kandilli Rasathanesi ve Deprem Araştırmaları Enstitüsü. "İstanbul Metropolitan Alanının Deprem Risk Analizi”.

http://www.koeri.boun.edu.tr/arastirma_3.depmuh (02.07.2019).

[2] Erdik M, Durukal E. "Earthquake risk and its mitigation in Istanbul". Natural Hazards, 44, 181-197, 2008.

[3] Yu X, Zhang Y. "Sense and avoid technologies with applications to unmanned aircraft systems: review and prospects". Progress in Aerospace Sciences, 74, 152-166, 2015.

[4] Griffin GF. "The use of unmanned aerial vehicles for disaster management". Geomatica, 68(4), 265-281, 2014.

[5] Liu P, Chen AY, Huang YN, Han JY, Lai JS, Kang SC, Wu TH, Wen MC, Tsai MH. "A review of rotorcraft unmanned aerial vehicle (UAV) developments and applications in civil engineering". Smart Structures and Systems, 13(6), 1065-1094, 2014.
[6] Mersheva V. UAV Routing Problem for Area Monitoring in a Disaster Situation. PhD Thesis, Alpen-Adria Universitat, Klagenfurt, Austria, 2015.

[7] Nedjati A, Vizvari B, Izbirak G. "Post-earthquake response by small UAV helicopters". Natural Hazards, 80, 1669-1688, 2016.

[8] Zhu M, Du X, Zhang X, Luo H, Wang G. "Multi-UAV rapidassessment task-assessment problem in a post-earthquake scenario". IEEE Access, 7, 74542-74557, 2019.

[9] Coutinho WP, Battarra M, Fliege J. "The unmanned aerial vehicle routing and trajectory optimisation problem, a taxonomic review". Computers \& Industrial Engineering, 120, 116-128, 2018.

[10] Seyis A, Karacin Y, Ozkan O. "Optimal path planning with minimum number of UAVs by using genetic algorithm". $28^{\text {th }}$ European Conference on Operational Research (EURO 2016), Poznan, Poland, 3-6 July 2016.

[11] Ozkan 0. "Insansız hava araçları ile Türkiye'deki orman yangınlarının tespiti probleminin tavlama benzetimi ile eniyilenmesi". 38. Ulusal Yöneylem Araștırması ve Endüstri Mühendisliği Kongresi (YAEM 2018), Eskişehir, Türkiye, 26-29 Haziran 2018.

[12] Kaya M, Ozkan 0. "Sınır koruma görevi için insansız hava araçlarının rotalanması probleminin genetik algoritma ile eniyilenmesi". 38. Ulusal Yöneylem Araştırması ve Endüstri Mühendisliği Kongresi (YAEM 2018), Eskişehir, Türkiye, 26-29 Haziran 2018.

[13] Ercan C, Gencer C. "Dinamik insansiz hava sistemleri rota planlaması literatür araştırması ve insansız hava sistemleri çalışma alanları". Pamukkale Üniversitesi Mühendislik Bilimleri Dergisi, 19(2), 104-111, 2013.

[14] Sahin Y, Karagul K. "Gezgin satıcl probleminin melez akışkan genetik algoritma (MAGA) kullanarak çözümü". Pamukkale Üniversitesi Mühendislik Bilimleri Dergisi, 25(1), 106-114, 2019.

[15] Tsiligirides, T. "Heuristic methods applied to orienteering". Journal of the Operational Research Society, 35(9), 797-809. 1984.

[16] Golden BL, Levy L, Vohra R. "The orienteering problem". Naval Research Logistics, 34(3), 307-318, 1987.

[17] Ramesh R, Yoon YS, Karwan MH. "An optimal algorithm for the orienteering tour problem". ORSA Journal of Computing, 4(2), 155-165, 1992.

[18] Chao IM, Golden BL, Wasil EA. "A fast and effective heuristic for the orienteering problem". European Journal of Operational Research, 88(3), 475-489, 1996.

[19] Feillet D, Dejax P, Gendreau M. "Traveling salesman problems with profits: An overview". ORP 3 Conference, Paris, France, 26-29 September, 2001.

[20] Fomin FV, Lingas A. "Approximation algorithms for timedependent orienteering". Information Processing Letters, 83, 57-62, 2002.

[21] Boussier S, Feillet D, Gendreau M. "An exact algorithm for the team orienteering problem". 40R, 5(3), 211-230, 2007.

[22] Righini G, Salani M. "Decremental state space relaxation strategies and initialization heuristics for solving the orienteering problem with time windows with dynamic programming". Computers \& Operations Research, 36(4), 1191-1203, 2009. 
[23] Bouly H, Dang DC, Moukrim A. "A memetic algorithm for the team orienteering problem". 40R, 8(1), 49-70, 2010.

[24] Tricoire F, Romauch M, Doerner KF, Hartl RF. "Heuristics for the multi-period orienteering problem with multiple time windows". Computers \& Operations Research, 37(2), 351-367, 2010.

[25] Campbell AM, Gendreau M, Thomas BW. "The orienteering problem with stochastic travel and service times". Annals of Operations Research, 186(1), 61-81, 2011.

[26] Labadie N, Mansini R, Melechovsky J, Calvo WR. "Hybridized evolutionary local search algorithm for the team orienteering problem with time windows". Journal of Heuristics, 17(6), 729-753, 2011.

[27] Vansteenwegen P, Souffriau W, Van Oudheusden D. "The orienteering problem: A survey". European Journal of Operational Research, 209(1), 1-10, 2011.

[28] Labadie N, Mansini R, Melechovsky J, Calvo WR. "The team orienteering problem with time windows: An LP-based granular variable neighborhood search". European Journal of Operational Research, 220(1), 15-27, 2012.

[29] Lin SW, Yu VF. "A simulated annealing heuristic for the team orienteering problem with time windows". European Journal of Operational Research, 217(1), 94-107, 2012.

[30] Afsar HM, Labadie N. "Team orienteering problem with decreasing profits". Electronic Notes in Discrete Mathematics, 41, 285-293, 2013.

[31] Archetti C, Bianchessi N, Speranza MG. "The capacitated team orienteering problem with incomplete service". Optimization Letters, 7(7), 1405-1417, 2013.

[32] Dang DC, Guibadj RN, Moukrim A. A Branch-And-Cut Algorithm for Solving the Team Orienteering Problem. Editors: Gomes C., Sellmann M. Integration of AI and OR Techniques in Constraint Programming for Combinatorial Optimization Problems (CPAIOR 2013) Lecture Notes in Computer Science, vol 7874, Berlin, Heidelberg, Springer, 2013.

[33] Divsalar A, Vansteenwegen P, Cattrysse D. "A variable neighborhood search method for the orienteering problem with hotel selection". International Journal of Production Economics, 145(1), 150-160, 2013.

[34] Lin SW. "Solving the team orienteering problem using effective multi-start simulated annealing". Applied Soft Computing, 13(2), 1064-1073, 2013.

[35] Özdemir M. Zaman Kısıtı Altında Takım Oryantiring Problemlerinin Yapay Arı Kolonosi Yaklaşımı ile Çözümü. Yüksek Lisans Tezi, İstanbul Üniversitesi, İstanbul, Türkiye, 2013.

[36] Tarantilis CD, Stavropoulou F, Repoussis PP. "The capacitated team orienteering problem: A bi-level filterand-fan method". European Journal of Operational Research, 224(1), 65-78, 2013.

[37] Angelelli E, Archetti C, Vindigni M. "The clustered orienteering problem". European Journal of Operational Research, 238(2), 404-414, 2014.

[38] Campos V, Marti R, Sanchez-Oro J, Duarte A. "GRASP with path relinking for the orienteering problem". Journal of the Operational Research Society, 65(12), 1800-1813, 2014.

[39] Cura T. "An artificial bee colony algorithm approach for the team orienteering problem with time windows". Computers \& Industrial Engineering, 74, 270-290, 2014.
[40] Evers L, Glorie K, van der Ster S, Barros AI, Monsuur H. "A two-stage approach to the orienteering problem with stochastic weights". Computers \& Operations Research, 43, 248-260, 2014.

[41] Hu Q, Lim A. "An iterative three-component heuristic for the team orienteering problem with time windows". European Journal of Operational Research, 232(2), 276-286, 2014.

[42] Salazar-Aguilar MA, Langevin A, Laporte G. "The multidistrict team orienteering problem". Computers \& Operations Research, 41, 76-82, 2014.

[43] Verbeeck C, Sörensen K, Aghezzaf EH, Vansteenwegen P. "A fast solution method for the time-dependent orienteering problem". European Journal of Operational Research, 236(2), 419-432, 2014.

[44] Zhang S, Ohlmann JW, Thomas BW. "A priori orienteering with time windows and stochastic wait times at customers". European Journal of Operational Research, 239(1), 70-79, 2014.

[45] Duque D, Lozano L, Medaglia AL. "Solving the orienteering problem with time windows via the pulse framework". Computers \& Operations Research, 54, 168-176, 2015.

[46] Gavalas D, Konstantopoulos C, Mastakas K, Pantziou G, Vathis N. "Approximation algorithms for the arc orienteering problem". Information Processing Letters, 115, 313-315, 2015.

[47] Gunawan A, Lau HC, Lu K. "Well-Tuned ILS for Extended Team Orienteering Problem with Time Windows". Living Analytics Research Center, Singapore, Technical Report, 2015.

[48] Lin SW, Yu VF. "A simulated annealing heuristic for the multiconstraint team orienteering problem with multiple time windows". Applied Soft Computing, 37, 632-642, 2015.

[49] Marinakis $\mathrm{Y}$, Politis M, Marinaki M, Matsatsinis N. A Memetic-GRASP Algorithm for the Solution of the Orienteering Problem. Editors: Le Thi HA, Dinh TP, Nguyen N.T. Modelling, Computation and Optimization in Information Systems and Management Sciences, Advances in Intelligent Systems and Computing: 360, 105-116, Switzerland, Springer, 2015.

[50] Gunawan A, Lau HC, Vansteenwegen P. "Orienteering Problem: A survey of recent variants, solution approaches and applications". European Journal of Operational Research, 255, 315-332, 2016.

[51] Yu J, Schwager M, Rus D. "Correlated orienteering problem and its application to persistent monitoring tasks". IEEE Transactions on Robotics, 32(5), 1106-1118, 2016.

[52] Ostrowksi K, Karbowska-Chilinska J, Koszelew J, Zabielski P. "Evolution-inspired local improvement algorithm solving orienteering problem". Annals of Operations Research, 253, 519-543, 2017.

[53] Hu W, Fathi M, Pardolos PM. "A multi-objective evolutionary algorithm based on decomposition and constraint programming for the multi-objective team orienteering problem with time windows". Applied Soft Computing Journal, 73, 383-393, 2018.

[54] Tsakirakis E, Marinaki M, Marinakis Y, Matsatsinis N. "A similarity hybrid harmony search algorithm for the team orienteering problem". Applied Soft Computing Journal, 80, 776-796, 2019. 
[55] Holland JH. Adaptation in Natural and Artificial Systems, Michigan, USA, University of Michigan Press, 1975.

[56] Aarts E, Korst J. Simulated Annealing and Boltzmann Machines: A Stochastic Approach to Combinatorial Optimization and Neural Computing, New York, USA, Wiley, 1989.

[57] Türk Mühendis ve Mimar Odaları Birliği (TMMOB). "İstanbul Deprem Raporu" https://www.tmmob.org.tr/sites/default/files/rapor_20 17_son.pdf (02/07/2019).
[58] T.C. Çevre ve Şehircilik Bakanlığı. "İstanbul Deprem Bölgeleri Dağılımı Haritası". https://istanbulakdm.csb.gov.tr/istanbul-deprembolgeleri-dagilimi-haritasi-i-3712 (02/07/2019).

[59] Türkiye İstatistik Kurumu "Merkezi Dağıtım Sistemi". https://biruni.tuik.gov.tr/medas/?kn=95\&locale=tr (02/07/2019).

[60] Atlasbig. "İstanbul Mahalleleri Nüfus Yoğunluğu". https://www.atlasbig.com/tr/istanbul-mahallelerinufus-yogunlugu (02/07/2019). 